\title{
Relevance of Anti-corruption Education Values with Pancasila Basic Values and its Strengthening Efforts
}

\author{
Sumaryati Sumaryati \\ Program Studi Pendidikan Pancasila dan Kewarganegaraan \\ Universitas Ahmad Dahlan \\ Yogyakarta, Indonesia \\ sumaryati@ppkn.uad.ac.id
}

\begin{abstract}
Anti-corruption education is one of the government's policies, which aims to create a generation of anticorruption spirits. The generation that understands the negative impact of corruption, which always embodies the values of anticorruption education in every day's activities. Generations who understand that anti-corruption are attitudes and behaviors that are in line with the values of Pancasila as the basic of the State. In reality, not all people understand the values of anti-corruption education, even though this is an important basic for anticorruption attitudes. To facilitate public understanding of anticorruption values, as well as to ground the values of Pancasila in the increasingly widespread problems of corruption, a more indepth study of the relevance of anti-corruption education values with Pancasila values is needed. This study aims to determine the relationship between the values of anti-corruption education and the values of Pancasila, and how to strengthen anti-corruption education, as an effort to actualize the values of Pancasila. This type of research is descriptive qualitative literature. The object of research is a reference in the form of a book, the results of previous studies that discussed the values of Pancasila and anticorruption education. Data collection method through literature study. Data analysis was descriptive qualitative, with steps of analysis, data reduction, data display, data analysis, and conclusion. The results of the study show that there is relevance between the values of anti-corruption education and the values of Pancasila. Honesty is relevant to the value of divinity and humanity. Concern is relevant to divine values and humanity. Independence is relevant to the value of unity. Discipline is relevant to the value of unity. Hard work is relevant to the value of justice. Responsibility is relevant to the value of justice. Simplicity is relevant to humanity and justice. Courage is relevant to popular values. Justice is relevant to the value of humanity and the value of justice. Strengthening anti-corruption education needs to be done to strengthen the values of Pancasila. Strengthening anti-corruption education can be done by (1) introduction of corruption phenomena, such as corruption, causes of corruption, and consequences, (2) promotion of corruption, (3) showing the possibility of fighting corruption, (4) Essential things, such as value and capacity building, included in the general education curriculum.
\end{abstract}

Keywords-the general education curriculum; the introduction of anti-corruption; the value of anti-corruption education; the value of Pancasila; the promotion of anti-corruption

\section{INTRODUCTION}

Bung Hatta stated that the hardest struggle was how to fight your own people. The destruction or failure of a person or a nation is determined more by internal factors, factors that come from within yourself. These internal factors are related to mentality. The Indonesian people can experience failure due to the Indonesian mental factors themselves. Phenomenologically, the Indonesian people experienced degradation. The loss of shame, often lies or is dishonest, greedy, does not dare to defend the truth, from leaders and some people, as an example of mental degradation. Corruption is an example of the impact of mental degradation.

Corruption, which is known as an extraordinary crime, has a tremendous impact. All segments of the life of the nation and state, both social, political, legal, cultural, economic and security, become weak. Corruption will result in failure to achieve goals. Thus corruption is an action that is contrary to the values of Pancasila, which is the basis and objective of the Indonesian state. Criminal acts of corruption, clearly deviate from the values of divinity, humanity, unity, popularness and social justice. The criminal act of corruption deviates from God's commands, harms many others, results in dividing the community and several parties, leaving the process of consensus and unjust deliberation. Given the massive impact of corruption, it is necessary to strive to eradicate and prevent acts of corruption. Eradication of corruption is done by law enforcement, prevention of corruption is carried out, among others, with anti-corruption education / education.

Anti-corruption education according to UU No. 30 of 2002, was handled by the Indonesian Education and Services SubSector, the Corruption Eradication Commission (KPK), under the coordination of the KPK Prevention Division. The existence of these fields and subfields is expected to strengthen the task of the Corruption Eradication Commission (KPK) in taking action to prevent corruption [1]. Eko Handoyo states that anti-corruption education is absolutely necessary to strengthen corruption eradication, through system reform (constitutional reform), institutional reform (institutional reform), and law enforcement [2]. Azra states that anticorruption education is an attempt to reform political culture through the education system to carry out sustainable cultural change, and encourage the creation of good governance culture in schools and universities [3].

Agus Wibowo, stated that there were several reasons for the importance of anti-corruption education in schools. The reason is that the world of education has a set of knowledge to enlighten various misunderstandings in the effort to eradicate corruption, educational institutions have strong networks 
throughout the country, so anti-corruption education can be massive, and corruptors are generally smart people, so educational institutions are in charge not only gave birth to smart people but at the same time a noble-hearted person [4]. Rosida Tiurma Manurung, states that in order for education in the modern era to be high-tech, not only to produce people like machines, who do not have a sense of humanity, then education must be packed with integrity and humanistic perspective [5]. Education must be able to develop positive values in students, so that a character with strong personality and proven personality is born, both in the scientific field and in the humanitarian field. According to Rosida, anti-corruption education is in line with the characteristic and humanistic education [5]. Anti-corruption education is expected to be the main foundation for the formation of an honest identity, the Pancasila paradigm, the 1945 Constitution, in accordance with Law No. 20 of 2003 [6]. Efforts to prevent corruption carried out by the KPK, with anti-corruption education policies, received positive response from the Ministry of National Education. In the Minister of National Education Regulation No.22 of 2006 concerning Standard Content for primary and secondary education units, the substance of anti-corruption education is formulated in the curriculum of class V, VIII, and $\mathrm{X}$ in semester I [7].

The importance of anti-corruption education in the world of education or school, then consequently on the existence of efforts to find the right strategy to incorporate the values of anti-corruption education in the education system. Because there are already so many subjects or courses, the strategy that is most likely to be considered is how to insert / insert anticorruption material in all subjects. Schools and colleges have a strategic role in cultivating anti-corruption behavior among students and students. Sumaryati and Anom Wahyu Asmorojati's research entitled Internalization Model of AntiCorruption Education Values in SMA 3 Bantul (2014) states that teachers in SMA 3 Bantul have integrated the values of anti-corruption education in the learning process, by including values that will be developed and realized in the learning process in the learning implementation plan (RPP) [8]. The learning model used by the teachers of Bantul 3 State Senior High School in an effort to integrate values is a student centered (though not optimal) model. Method of teacher of Bantul 3 State Senior High School in integrating the values of anti-corruption education in the learning process is not yet varied and creative, it is still limited to class discussion methods, and evaluation of the learning process carried out by teachers of SMA Negeri 3 Bantul is giving assignments to present each task given teacher. Evaluations in the form of anecdotal records have not been fully carried out by the teacher. The results of this study indicate that the improvement and strengthening of anti-corruption education must still be carried out continuously, so that the aims and intentions of anticorruption education can be realized.

Anti-corruption education is a conscious and planned effort to realize the teaching and learning process that is critical to the values of anti-corruption. Thus anti-corruption education does not merely emphasize cognitive aspects or knowledge alone, but also emphasizes the formation of character (affective), and moral awareness in fighting corruption. Agus Wibowo in his book, stated "anti-corruption education aims to create a young generation that has good morals and anti-corrupt behavior" [4]. Furthermore Agus Wibowo, also stated that anti-corruption education to build children's character from an early age, so as not to commit corruption. The anti-corruption mentality must be implemented early on, then in the next few years there will be generations of anti-corruption. Anti-corruption education is an education that is very important in developing anticorruption mentality or character, and is very important for the development of Indonesia. Anti-corruption education basically teaches, understands, and habituates, and develops anticorruption values [4].

The values of anti-corruption education that are accustomed since childhood are honesty, caring, independence, discipline, responsibility, hard work, simplicity, courage, and justice [9]. Anti-corruption education is actually a value education. Value education in anti-corruption education is indirectly the value education contained in Pancasila. Anti-corruption education is an important part of the education of the value of Pancasila, which is the character of the nation. So there is relevance between the values of anti-corruption education and the values of Pancasila. This study aims to determine the relationship between the values of anti-corruption education and the values of Pancasila, and how to strengthen anti-corruption education, as an effort to actualize the values of Pancasila

\section{METHOD}

This research is a descriptive qualitative library research. Descriptive method will be used in research steps, from research preparation, data collection, and data analysis process [10]. The research stages are data collection, data reduction, data analysis, and conclusion. Data collection is carried out using library research methods. The literature research method is used to conduct data inventory concepts on Pancasila and anti-corruption education. Data from reading results, then recorded, either in the form of quotations, paraphrases, synoptic or summary, and precisions or compaction. The conclusions were drawn from a comparison analysis of the values of anti-corruption education with the values of Pancasila.

\section{RESULT AND DISCUSSION}

The results of the study will describe the values of anticorruption education, the values of Pancasila, the relevance of anti-corruption education values with the values of Pancasila, and end with efforts to develop and strengthen anti-corruption education as national character education.

Substantially anti-corruption education is actually value education. Education that is able to convey and implement moral messages. Education that touches physical and mental aspects. Education that uses thought, though heart, volition, and physical processing collaboratively. Education that touches on cognitive, affective, and psychomotor aspects. Education emphasizes the process and changes in intentions, changes in mind set, and changes in attitude and behavior. Anti-corruption education is education that is full of value. In his book Agus Wibowo, mentioning the values of anti-corruption are honesty, caring, independence, discipline, responsibility, hard work, 
simplicity, courage, and justice. The value of honesty is a behavior that is based on the effort to make himself a person who can always be trusted in words, actions, and work [4]. The value of caring is the attitude and actions that always want to help others and the people in need. The value of independence is attitudes and behaviors that are not easily influenced by others in completing tasks. The value of discipline is an act that shows orderly behavior and adheres to various rules and regulations. The value of responsibility is the attitude and behavior of a person to carry out his duties, which he should do, to himself, the community, the environment (natural, social, cultural), the state, and the Almighty God. The value of hard work is a behavior that shows a sincere effort in obeying various barriers to learning and tasks, as well as completing the task as well as possible. The value of simplicity is unpretentious, attitude and behavior are not excessive, not a lot of ins and outs, not a lot of trinkets, straightforward, as is, economical as needed, and humble. The value of courage is to have a strong nature and great self-confidence in facing danger, difficulty, fearlessness, and never retreat. The value of justice is equally heavy, not biased, not favoritism, siding with the truth, rightly, not arbitrary, neutral, objective, and proportional. All the values of anti-corruption education lead to one term, integrity. A person with integrity is someone who is always honest, disciplined, dares to admit mistakes, dare to apologize, dare to be reprimanded, dare to rebuke others who are guilty or not according to the norm. These values must be delivered using a humanistic and pleasant strategy.

Anti-corruption education as value education must be based and in accordance with the basis of Indonesia's national education, Pancasila. Pancasila as the basis of the state in its implementation is then translated into other functions of Pancasila. One of the functions of the Pancasila derivative is the State ideology. Pancasila as an ideology there are three aspects, namely logos aspect, patos aspect and ethos aspect [11]. If people understand Pancasila correctly (logos aspect), then there will be a belief that Pancasila is the best for the Indonesian people (aspects of pathos). If there is already such a belief, there will be a belief that with Pancasila the Indonesian people will become a large and advanced nation, and if proven, there will be a sense of belonging and strive to maintain and develop Pancasila values, with actions (aspects of ethos). Understanding Pancasila values is properly studied in the essence of each Pancasila principle. The essence of the divine value is the recognition of the substance which is the first cause of everything that exists, which is not caused by others. The essence is one, perfect, power, eternal, obeyed, and accepted. Humanitarian value is a monopluralist creature, a creature that consists of many elements but is a unity. The value of unity is not separate, indivisible. Population value is consensus based on the best and most sound, not the most. The value of social justice is the proportionality of the suitability of obligations with rights, in human relations with oneself, with others, with God [11]. These Pancasila values are abstract, not yet operational. Then the media is needed to implement and develop it. One of the media is with anti-corruption education policy. Because anti-corruption education is a follow-up and complementary to Indonesia's national education system, to realize the goals of national education, which is nothing but the implementation of the values of Pancasila.
The relevance of anti-corruption education values with the values of Pancasila, as follows. Honesty is relevant to the divine value (the first precepts of Pancasila) and human values (the second principle of Pancasila). Honesty is an attitude that is maintained and practiced by any religion. Honesty is also relevant to humanity, because honesty means that someone respects and respects people Another concern is very relevant to human values (the second precept of Pancasila), human beings who have concern means having humanity. Edependence means that a person has a strong principle, is not easily influenced, tempted by others, so that this will greatly help the realization of community unity (sila third Pancasila) Discipline, as an act that shows orderly and obedient behavior in various rules and regulations, will greatly facilitate unity (the third principle of Pancasila) Hard work, behavior that demonstrates earnest efforts in overcoming various learning barriers and tasks, and solve it in the task as well as possible, is one of the efforts to realize the value of social justice (the fifth principle of Pancasila). Responsibility, understood as an attitude and behavior of a person to carry out his duties and obligations, which he should do, to himself, society, environment (natural, social, cultural), the state, and God Almighty, is one manifestation of the value of social justice (the fifth principle of Pancasila). Simplicity, understood as an understated attitude, attitude and behavior that is not excessive, straightforward, what it is, economical according to need, and humble, very much in line with humanity values (the second principle of Pancasila) and the value of social justice (the fifth principle of Pancasila), able to maintain solidarity among community members. Courage, humans have a strong nature and great self-confidence in facing danger, difficulties, fearlessness, and never retreat, are very relevant to realize popular democracy (the fourth principle of Pancasila). Justice, understandable attitude that is equally heavy, not biased, not favoritism, siding with the truth, not arbitrary, neutral, objective, and proportional, is very relevant to the value of social justice (the fifth precept of Pancasila) and also the value of humanity (second precept Pancasila).

The description above shows how closely the values in anti-corruption education with values in Pancasila. If in the generation of Indonesia, anti-corruption values have been embedded, meaning in the Indonesian generation, the values of Pancasila have been embedded. It is important to strengthen anti-corruption education continuously in all levels of Indonesian society, as an effort to strengthen Pancasila values in Indonesian society. Strengthening anti-corruption education in accordance with the Center for Modern Educators (2006: 19), is carried out through (1) the introduction of corruption phenomena, such as corruption, corruption and consequences, (2) promotion of corruption refusal, (3) the possibility of fighting corruption, (4) including points Key points that are ready to be included in the general education curriculum, such as value and capacity building. Such values, such as respect for democracy, honesty, responsibility for behavior and behavior, are always independent, such as building social, cultural and knowledge competencies. Strengthening capacity, including communication, finding, processing and sending information, critical thinking and problem solving, rational planning and organizing activities, managing time, managing resources, 
creative, communicative and cooperative activities, solving constructive disputes and conflicts [12].

\section{CONCLUSION}

There is relevance between the values of anti-corruption education and the values of Pancasila. Honesty is relevant to the first principle and the second principle of Pancasila (divine and human values). Concern is relevant to the first principle and the second principle of Pancasila (divine and humanity values). Independence is relevant to the third principle of Pancasila (the value of unity). Discipline is relevant to the third principle of Pancasila (the value of unity). Hard work is relevant to the fifth principle of Pancasila (the value of justice). Responsibility is relevant to the fifth principle of Pancasila (the value of justice). Simplicity is relevant to the second and fifth precepts of Pancasila (humanity and justice values). Courage is relevant to the fourth principle of Pancasila (popular values). Justice is relevant to the second and fifth precepts of Pancasila (the value of humanity and the value of justice).

\section{REFERENCES}

[1] UU No. 30 tahun 2002 Tentang Komisi Pemberantasan Tindak Pidana Korupsi.

[2] H. Eko, Pendidikan Antikorupsi, edisi Revisi, Yogyakarta: Ombak, 2013.

[3] A. Azra, Kata Pengantar Pendidikan Antikorupsi Mengapa Penting, dalam Karlina Helmanita dan Sukron Kamil, Pendidikan Antikorupsi di Perguruan Tinggi, Jakarta: CSRC UIN Syarif Hidayatullah Jakarta, 2006.

[4] W. Agus, Pendidikan Antikorupsi di Sekolah, Strategi Internalisasi Pendidikan Antikorupsi di Sekolah, Yogyakarta: Pustaka Pelajar, 2013.

[5] T.M. Rosida, "Pendidikan Antikorupsi sebagai Satuan Pembelajaran Berkarakter dan Humanistik," Jurnal Sosioteknologi, vol. 11, no. 27, 227-239, 2012.

[6] UU No. 20 Tahun 2003 Tentang Sistem Pendidikan Nasional.

[7] Peraturan Menteri Pendidikan Nasional No. 22 tahun 2006 tentang Konten Standar untuk unit pendidikan dasar dan menengah.

[8] Sumaryati and W.A. Anom, Internalization Model of Anti-Corruption Education Values in SMA 3 Bantul, 2014.

[9] Kemendikbud Dirjendikti, Pedoman pelaksanaan Pendidikan Karakter (berdasarkan pengalaman di Satuan Pendidikan Rintisan), Jakarta: Kementrian Pendidikan Nasional Badan Penelitian dan Pengembangan Pusat Kuriukulum dan Perbukuan, 2011.

[10] Kaelan, Metode Penelitian Filsafat, Yogyakarta: Paradigma, 2005.

[11] Kaelan, Filsafat Pancasila, Yogyakarta: Paradigma, 1998.

[12] D. Penkauskiene, Anti-Corruption Education at School Methodical Material for General and Higher Education Schools, Vilnius: Garnelis Publishing, 2006. 